\title{
TYPY WIEDZY TEORETYCZNEJ
}

W ciągu dziejów ukształtowało się kolejno wiele epistemologicznie różnych typów teoretycznej wiedzy. Nie trudno zauważyć, że zawsze istniała tendencja traktowania jednego tylko typu wiedzy za bezwzględnie najwartościowszy i wzorowy dla każdego szanującego się uczonego lub. filozofa. Przeważnie wybierano najnowszą koncepcję nauki lub filozofii, a dokładniej mówiąc, ideałem teoretycznej wiedzy od XVIII wieku stała się fizyka (często również mawiano - matematyczne przyrodoznawstwo). Otóż wydaje się, że nie ma dostatecznych racji, aby ustalać absolutnie obowiązujący jeden typ teoretycznej wiedzy lub każde działanie opierać o ten sam typ teoretycznej wiedzy, gdyż wartość epistemologiczna wiedzy może być wyznaczana jedynie w sposób zrelatywizowany do harmonijnego preferowania odmiennych celów poznania i ze względu na określony przedmiot poznania. Należy brać pod uwagę nie tylko zresztą spełnione zadania samej wiedzy, lecz także przewidywane jej zastosowania praktyczne (owoce wiedzy).

Aby uzasadnić postawioną hipotezę o względności kwalifikacji epistemologicznej a więc tego, że jakiś typ teoretycznej wiedzy jest cenniejszy wyłącznie $\mathrm{z}$ uwagi na określone okoliczności, przedstawię definicję wiedzy teoretycznej, jej podstawowe typy epistemologiczne oraz kryteria ich odróżniania i wartościowania. Rozważania te same należą do pewnego typu wiedzy teoretycznej, a mianowicie filozofii poznania, dlatego postaram się prowadzić je epistemologicznie ostrożnie, czyli przyjmując najmniej kontrowersyjne założenia i wymieniając je wyraźnie, aby wiadomo było, co warunkuje uzasadniane tezy.

Wiedzą teoretyczną nazywa się na ogół poznanie, które jest pod względem epistemologicznym i metodologicznym zaawansowane tudzież o charakterze wyjaśniającym, choćby $\mathrm{w}$ szerokim tego ostatniego terminu sensie. To zaawansowanie wiedzy ma miejsce wtedy, gdy jest ona specjalistyczna (zasadniczo ujmuje swój przedmiot'w jednym aspekcie czyli pod jednym kątem), empirycznie (przynajmniej genetycznie) lub racjonalnie uprawomocniona w sposób kontrolowalny, treściowo i logicznie uporządkowana oraz wyrażona w języku informatywnym (in. 
tersubiektywnie, czyli jednoznacznie zrozumiałym przez ogół fachowców). Poznanie zaś ma charakter wyjaśniający, jeśli obiektywnie zasadnie odpowiada wprost albo pośrednio na pytanie, dlaczego tak jest, było lub być powinno. Teoria bowiem przeciwstawia się tu wiedzy czysto opisowej i potocznej, a więc powiązanej tylko koniunkcyjnie a nie jakimś rodzajem wynikania, oraz nieusystematyzowanej i doraźnie zdobywanej dla subiektywno-utylitarnych celów.

Inaczej mówiąc teoretyczna wiedza jest dowodowo usystematyzowaną (inferencyjnie powiązanym układem zdań o jednolitej dziedzinie), empirycznie uprawomocnioną i jednoznacznie sformułowaną odpowiedzią na pytania, żądające wytłumaczenia zaobserwowanych, lub przez dotychczasową wiedzę danych sytuacji. Wydaje się, że określenie to nie jest za ciasne, obejmuje bowiem różne odmiany wiedzy ściśle naukowej i filozoficznej. Chce również uniknąć kontrowersji między aprioryzmem a empiryzmem (dlatego nie wyznacza bliżej sposobu połączenia teorii z doświadczeniem) oraz między diachronicznym a synchronicznym traktowaniem kryteriów naukowości. Atoli dyskusyjna pozostaje sprawa zaliczenia aksjologii czyli filozofii wartości do teoretycznej wiedzy. Otóż można przytoczyć wiele racji za tym, że teoria wartości absolutnych ${ }^{1}$, pojętych jako pewne nietreściowe lecz strukturalno-ontyczne aspekty bytu mieści się w ramach teorii rzeczywistości. Tradycja epistemologiczna jednak zalicza aksjologię do poznania praktycznego, wiążąc ją z etyką i estetyką. Subiektywiści nowocześni zaś w ogóle eliminują aksjologię z zakresu rzetelnej wiedzy.

$\mathrm{Z}$ punktu widzenia epistemologii rozróżnia się fundamentalne typy wiedzy teoretycznej ze względu na zadanie (cel przedmiotowy), jakie i w jaki sposób osiąga' poznanie. Każda wiedza teoretyczna stanowi zdobyte różnymi drogami wyjaśnienie tego, co dane, czyli wskazuje w szerokim sensie tego słowa przyczyny danego w doświadczeniu świata czy samego człowieka na gruncie odpowiedniej wiedzy dotychczasowej. Typy tych przyczyn sprowadzić można do 4 grup: $1^{\circ}$ stany rzeczy wcześniejsze $w$ stosunku do danego albo sprawca-podmiot tego, co dane, $2^{\circ}$ idealne albo realne formy i typy niezmienne danych rzeczy czy też ich egzystencjalna infrastruktura, $3^{\circ}$ racjonalnie przewidywane stany rzeczy, do których skierowane są dane procesy, $4^{\circ}$ stałe relacje (lub system takich relacji) zachodzące między danymi stanami rzeczy albo w samych tych stanach rzeczy.

Nie trudno zauważyć, że takie uporządkowanie zadań wiedzy teoretycznej zakłada pewną ontologię czyli teorię przedmiotów. Trzeba

1 Wartość absolutna czyli wsobna jest kwalifikacją celu, a względna czyli instrumentalna stanowi kwalifikaację środkia do olkreślonego celu. Coś ma wartość wsobną wówczas, gdy aktualizuje swoją istotę (formę, ideę). 
ją tu zasygnalizować, aby można było szerzej wyeksplikować wspomniane 4 typy wiedzy teoretycznej.

Odróżniamy najpierw rzeczy od ich własności, relacji, aktów i innych przypadłości (akcydensów). Stanami rzeczy zaś nazywamy układy cech i innych przypadłości przysługujących rzeczom lub układy rzeczy. Zmiany cech lub stanów rzeczy to odpowiednio zdarzenia lub procesy (zjawiska) ${ }^{2}$. Rzeczy w najszerszym sensie dzielą się na substancje (osoby i inne) oraz bytu niesubstancjalne, a ponadto na istniejące niezależnie od działania człowieka (natura) i wytwory jego działalności (kultura). To, co dane w punkcie wyjścia poznania teoretycznego, może być albo zewnętrznym stanem rzeczy (naturą lub kulturą) ujętą w aspekcie jakościowym, ilościowym lub ogólnoegzystencjalnym), albo zawartością świadomości. Natomiast to, co może być przyczyną danego stanu rzeczy może być przypomniane lub mniemane albo skonstruowane częściowo (np. przez abstrakcję, idealizację) czy też całkowicie (np. w naukach formalnych przez układ założeń).

Wobec różnych danych przedmiotowo wziętych ze względu na przyjęte zadanie, stawia się rozmaite rodzaje pytań wiedzotwórczych, które można zgrupować ze względu na 4 typy poszukiwanych przyczyn.

Przy pierwszym typie pytamy: a) z czego (z jakich elementów) wywodzi się dany stan rzeczy (świat) - jonscy filozofowie przyrody, b) jaka jest geneza danego stanu rzeczy - tzw. wyjaśnienie genetyczne, c) kto albo co, jakie motywy lub dyspozycje działającego sprawią dany stan rzeczy lub proces. O drugi zaś typ przyczyny stawia się pytania: a) czego niezmiennego i koniecznego odbiciem jest to, co dane jako zmienne i przygodne - np. Platon, b) dzięki czemu (co stanowi istote czyli formę rzeczy i jaką hierarchię tworzą te formy) zachodzą takie a nie inne stany rzeczy - np. Arystoteles, c) dzięki czemu (jaka struktura wewnątrzbytowa powoduje, że istnieją takie i takie stany rzeczy ( $w$ aspekcie ogólnoegzystencjalnym) - np. Tomasz z Akwinu. Natomiast $w$ trzecim wypadku pytania dotyczą: a) tzw. przyczyny celowej wyjaśnianie teleologiczne, b) sensu życia i działan ludzkich (ich racjonalność), c) kierunku zachodzących procesów. A wreszcie w ostatnim typie mamy najbogatszy zbiór pytań: a) jaka jest ilościowo-czasowa struktura i dynamika stanów rzeczy - np. Galileusz, Newton, b) pod jakie aprioryczne kategorie umysłu podpadają dane o zjawiskach - Kant, c) jakie są prawidłowości strukturalne lub funkcjonalne zjawisk - np. pozytywiści, d) do jakiego prostszego modelu daje się sprowadzić dane zjawiska - wyjaśnianie modelowe, e) jaką pozycję zajmuje dany stan rze-

Za Kantem i pozytywistami zjawiskiem nazywa się tylko zdarzenie dane w doświadczeniu zewnętrznym; tu nie zacieśnia się terminów: zjawisko i fakt. 
czy lub dane zjawisko w większej całości - np. niektóre odmiany interpretacji humanistycznej.

W celu otrzymania odpowiedzi na powyższe typy pytań stosowane bywają różne metody. Można je rozmaicie poklasyfikować, ale tu zwrócimy uwagę jedynie na trzy zasadnicze odmienne sposoby tworzenia teorii: dedukcjonistyczny, indukcjonistyczny i redukcjonistyczny. W pierwszym przypadku naczelne lub dalsze przesłanki $w$ teorii intelektualnie odczytuje się $\mathrm{w}$ empirycznie danej rzeczywistości i dedukuje konsekwencje (np. Arystoteles), albo tworzy je czysto inwencyjnie i hipotetycznie w oparciu o całą dotychczasową wiedzę oraz próbuje obalić (empirycznie) wyprowadzone $\mathrm{z}$ nich konsekwencje (np. Popper), albo wreszcie zakładając opozycyjne tezy, w drodze dialektycznych analiz i syntez pojęciowych eliminuje się tezy fałszywe (np. Platon). Procedura indukcjonistyczna zaś polega na uogólnianiu danych doświadczenia przyjętych dogmatycznie i potwierdzaniu empirycznym uogólnień oraz ich systematyzowaniu; uogólnianie i potwierdzanie mogą posługiwać się mniej albo bardziej bogatymi środkami logiko-matematycznymi (np. F. Bacon, pozytywiści i neopozytywiści). Wreszcie redukcjonistycznie postępuje się wówczas, gdy szuka się jedynych racji dla zdań empirycznych, albo prostszych modeli dla układu zdań empirycznych, albo posługując się logiką i ontologiczną zasadą racji dostatecznej, sprowadza się zdania dane do zdań analitycznych (np. wyjaśnianie w klasycznej metafizyce, tzw. wyjaśnianie modelowe, Leibniz) ${ }^{3}$.

Jakie są zasady epistemologicznej preferencji wiedzy teoretycznej? Sprawa wyglądałaby prosto, gdyby prawdziwość mogła być kryterium akceptacji tez tej wiedzy. Klasyczne pojęcie prawdy jako niestopniowalnej właściwości zdania, aczkolwiek nie przestaje być kwalifikacją pożądaną dla wiedzy teoretycznej, to nie daje się jednak rozstrzygająco odnieść do większości twierdzeń teoretycznej wiedzy, której przedmiot jest przeważnie domniemany, lub przynajmniej częściowo skonstruowany. Funguje przeto wiele aspektów, w których jedna wiedza jest epistemologicznie wartościowsza od drugiej. Oceny w tych aspektach determinuje się opozycyjnie. I tak wartościowsza jest wiedza $1^{\circ}$ o większej prostocie, ale nie zmniejszająca adekwatności poznania, czyli nie upraszczająca rzeczywistości w aspekcie istotnym (dla wyjaśnienia lub zastosowań); dlatego redukcyjne wyjaśnianie modelowe nie dla każdego celu poznawczego może być stosowane, $2^{\circ}$ ogólniejsza, ale nie tracąca jednoznaczności, precyzji i siły empirycznego uprawomocnienia, $3^{\circ}$ bar-

3 Wymieniane cele przedmiotowe, pytania wiedzotwórcze i metody uzyskiwania wiedzy teoretycznej są elementarne i uproszczone. Zwykle bywają mieszane, bardziej złożone i to wielorako. Ale dla naszych dociekań nie wydaje się konieczne rozbudowywanie typologii, którą wyżej zaprezentowano. 
dziej zunifikowana, ale dająca się wedle jasnych zasad różnicować, $4^{\circ}$ pewniejsza, ale nie pozbawiona charakteru realności, $5^{\circ}$ empirycznie silniej uprawomocniona, ale nie ograniczająca ogólności i wykorzystania narzędzi logiko-matematycznych, a zwłaszcza twórczego myślenia. Należy więc harmonizować opozycyjne właściwości wedle stawianych zadań poznawczych i praktycznych oraz rodzaju wyjaśnianego przedmiotu. I tu dochodzimy do sedna sprawy. Różne funkcje wiedzy wymagają odmiennych zasad wartościowania jej.

Aby zdobyć np. teoretyczną wiedzę o zjawiskach przyrody martwej w zakresie poza mikro- i makrokosmicznym, stanowiącą podstawę minimalnego przekształcenia tej przyrody, wystarczy wyjść od danych doświadczenia zewnętrznego, pytać o stałe relacje między zjawiskami i posłużyć się metodą indukcjonistyczną. Inaczej rzecz ma się, gdy potrzebna jest wiedza teoretyczna o człowieku jako podstawa zasad jego wychowania perfekcjonistycznego (nie adaptacji. do typowego życia ludzi jemu podobnych!). Wtedy nie wystarczą odpowiednie prawidłowości zdobyte indukcyjnie (choćby $\mathrm{z}$ zastosowaniem najbogatszych środków logiko-matematycznych, np. statystyki) w oparciu o obserwacje (zewnętrzne) i introspekcję najbardziej licznych grup ludzi ${ }^{4}$. Nieadekwatna będzie też wiedza zdobyta przez redukcję do modelu właściwego dla zwierząt. Nieodzowna jest bowiem nadto teoretyczna wiedza o ontycznej naturze człowieka i jego egzystencjalnej pozycji nie tylko w świecie ożywionym, ale w ogóle wobec ontycznie ostatecznego jego celu (tylko wtedy można wybrać właściwą drogę choćby na odcinku doczesności; nie chodzi przecież o cel-wzór, jaki sobie tworzy społeczeństwo). Jeszcze nie koniec na tym. Dla pełności teoretycznej podstawy dla zasad wspomnianego wychowania potrzeba poznać nie tylko przyrodzony aspekt natury człowieka, lecz także nadprzyrodzony. Stąd płynie ważny wniosek dla teologii duszpasterskiej, która racjonalnie uzasadnia objawione reguły życia ku doskonałości. Nie może oprzeć się w tym wyłącznie na wiedzy otrzymanej metodami statystycznymi, gdyż nieodzowna jest filozofia (w klasycznym nie zaś scjentystycznym sensie) człowieka.

I jeszcze jeden przykład. Jeśli ktoś chce na podstawie wiedzy teoretycznej" rozstrzygnąc apodyktycznie twierdzenie o realnym istnieniu transcendentnego Absolutu, to nie może ograniczyć się do wiedzy, która nie byłaby tak ogólna, że aż transcendentalna (i analogiczna żeby nie

${ }^{4}$ Dane obserwacji zachowania się przedmiotów tylko wówczas pozwalają się uogólnić w prawa, jeśli panuje dostateczny determinizm zjawisk i dostateczna liczebność obserwacji w stosunku do jednorodności przedmiotów. Zjawiska kulturowe (człowieka, jego działań i wytworów) nie są zdeterminowane do końca przez czynniki zewnętrzne (zachodzi także autodeterminacja), stąd są bardzo niejednorodne. Dlatego statystyczne prawa zjawisk kulturowych nie mówią o naturze człowieka, lecz tylko o jego typowym zachowaniu. 
być wieloznaczną), empiryczna ale o dostatecznym stopniu takiego uteoretycznienia (analityczności), aby być pewną (chodzi o być albo nie być człowieka co do sensu życia). Okazuje się, że wymienione warunki spełnić może wyłącznie wiedza, pytająca o wewnętrzną infrastrukturę w aspekcie ogólnoegzystencjalnym (2c) i szukająca odpowiedzi redukcjonistycznie w tym sensie, że stara się wskazać jedyną rację dla stanów rzeczy ujętych jako następstwo. Tylko w aspekcie ogólnoegzystencjalnym ujmując rzeczywistość można uzyskać poznanie w pełni realistyczne, przekraczające kategorialne ograniczenia wszechświata (ale nie zupełnie wieloznaczne, bo analogiczne) i koniecznościowe (ujmuje intelektualnie w prosty sposób konieczne relacje w rzeczywistości i wyraża je w języku o charakterze analitycznym).

Zamykając dociekania na temat pluralizmu zasad epistemologicznego oceniania wiedzy teoretycznej, przynajmniej jako podstawy zasad działania (np. racjonalnych podstaw poglądu na świat, metodologii nauk, zasad wychowania człowieka, etyki) zauważyć można, że tylko nieznajomość typów wiedzy teoretycznej (ze względu na zadania poznawcze i przedmiot) i jej funkcji utylitarnych (zwłaszcza ideowo-wychowawczych) stoi na przeszkodzie relacyjnego wartościowania epistemologicznego wiedzy teoretycznej.

TYPES OF THEORETICAL KNOWLEDGE

Summary

In the paper epistemological characteristics relating to various kinds of theoretical knowledge are presented. In spite of dominance of physics in the contemporary scientific para digm one can distinguish many types of unphysical disciplines dealing with fundamental theoretical problems. The author analyses relationships between theoretical and practical knowledge taking into consideration principles of deductivism, inductivism, and reductionism. Having presented.pluralism of principles accepted in contemporary philosophy of science the author indicates the relativisation of assessements in this domain to specific purpose of given types of knowledge, 